\title{
Türkçe Dersi (1-8. Sınıflar) Öğretim Programı Sözlü İletişim Öğrenme Alanındaki Kazanımlara Eleştirel Bir
}

\author{
Bakış
}

\begin{abstract}
Gökhan ARI*
Öz

Dinleme/izleme ve konuşma becerileri, sözlü iletişimi oluşturan temel unsurlardır. Bir önceki programda dinleme/izleme ve konuşma kazanımları farklı öğrenme alanları iken 2015 yılında hazırlanan Türkçe Dersi (1-8. Sınıflar) Öğretim Programı'nda bu alanlar sözlü iletişim çatısı altında birleştirilmiştir. Bu çalışmanın amacı sözlü iletişim öğrenme alanındaki kazanımları özcü değerlendirme yaklaşımıyla değerlendirmek, kazanım ifadeleriyle ilgili sorunları tespit etmektir. Çalışmada nitel araştırma tekniklerinden doküman incelemesi kullanılmıştır. Program'da ardışıklık ve binişiklikle ilgili sorunlar belirlenmiş; kazanım ifadelerindeki muğlaklıklar, dinleme/izleme ve konuşma çerçevesinde, diğer öğrenme alanlarıyla ilişkilendirilerek irdelenmiştir. Sonuçta önceki öğretim programında ayrı ayrı işlenen bazı kazanımların yeni programda binişik şekilde ifade edildiği, kazanımlardan bazılarının sürekliliği bozduğu, bazılarının karmaşık, bazılarının eksik ve yanlış ifade edildiği belirlenmiştir. Bazı kazanımların daha doğru biçimde ifade edilmesi için öneriler sunulmuştur. Kazanım ifadelerindeki hataların, ölçme ve değerlendirme açısından birtakım sorunlara neden olabileceği öngörülmüştür.
\end{abstract}

Anahtar Kelimeler: Türkçe eğitimi, öğretim programı, öğrenme alanları, sözlü iletişim, dinleme/izleme, konuşma.

\section{A Critical View of Acquisitions in Oral Communication Learning Areas of Turkish Curriculum (1-8th Grades)}

\begin{abstract}
Listening/monitoring and speaking skills are the basic elements that compose/create oral communication. Listening/monitoring and speaking objectives have been combined in verbal communication in the 1-8th grade curriculum of the Turkish course made in 2015 while they were different learning areas at the previous programme. This study aims to evaluate the acquisitions in verbal communication learning area according to essentialist evaluation approach and to detect the problems in expressions of the acquisitions. Document review that is one of the qualitative research techniques were used in the study analysis. Sequantial and comorbidity problems have been identified in the programme; ambiguities in the expressions of acquisitions have been examined within the framework of listening/monitoring and speaking areas by associating with the other learning
\end{abstract}

\footnotetext{
* Düzce Üniversitesi, gokhanari@duzce.edu.tr
} 
areas. As a result (last of all), it has been determined that some acquisitions processed separately in the previous curriculum were expressed as comorbid in the new program, some acquisitions disrupt the continuity and some of them were expressed complex, some of them were expressed missing and the others were false. Last of all/consequently, some recommendations have been presented in order to express some acquisitions more accurately.

Anahtar Kelimeler: Turkish education, curriculum, learning areas, oral communication, listening/monitoring, speaking.

\section{GİRIŞ}

Bir dersin öğretim programı; toplumun ve bireylerin ihtiyaçları, teknolojik gelişmelerin etkisi göz önünde bulundurularak, eğitim felsefesi, tarihi, sosyolojisi, psikolojisi gibi temellerden hareket ederek var olan programdaki sorunların çözümü için gözden geçirilir ve belirli kuramlara, modellere, bağlantılara, araştırmalara bağlı olarak yenilenebilir. Yenilenen programın, paradigma değişimlerini dikkate alarak önceki programın uygulanmasında karşılaşılan sorunlara çözüm getirmesi, eksikleri gidermesi beklenir. Türkçe Dersi Öğretim Programı, bu unsurlara ve millî eğitim sistemindeki değişmelere (zorunlu eğitim, temel eğitim, ilkokulortaokul düzenlemeleri vs.) bağlı olarak yenilenmiştir. Yeni programın kademeli olarak

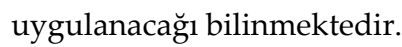

2015 yılında hazırlanan İlköğretim Türkçe Dersi (1-8. Sınıflar) Öğretim Programında; Türkçe dersi öğretim programı, programın temel yaklaşımı, programın genel amacı, programın yapısı, öğrenme alanları, ders ve öğretmen kılavuz kitabına alınacak metinlerin nitelikleri, ilk okuma yazma süreci, ölçme ve değerlendirme başlıkları bulunmaktadır. Bu başlıklardan sonra kazanımlar sınıf seviyelerine göre sıralandıktan sonra tablolaştırılmıştır.

Program'da, Program'ın öğrencinin birikim, beceri ve gelişimi göz önünde bulunduran ve öğrenciyi merkeze alan bir yaklaşımla hazırlandığı; bütün kazanımların sürekli gelişme ve ilerleme gösteren bir yapı içinde tasarlandığ 1 vurgulanmaktadır (MEB, 2015: 6). Öğrenme alanlarının birinci sınıftan sekizinci sınıfa kadar bir bütün olarak düşünüldüğü belirtilmektedir. Program'ın; öğrenme alanlarındaki kazanımlarla farklı türlerden metinler üzerinde çalışmalar yaparak anlama, anlamlandırma, değerlendirme ve sentezleme becerilerini geliştirmeye odaklandığı belirtilmektedir (MEB, 2015: 4).

Yeni program, 2005 yılından itibaren uygulanan İlköğretim Türkçe Dersi (1-5. Sınıflar) Öğretim Programı'ndan ve 2006'dan itibaren uygulanan İlköğretim Türkçe Dersi $(6,7,8$. Sınıflar) Öğretim Programı'ndan farklılıklar içermektedir. En önemli fark ilkokul, ortaokul ikiliğini tek bir çatıda toplamasıdır. Ancak teşkilat yapısı itibariyle şu anda ilkokul ve ortaokul farkının (sınıf sistemleri de değişebilir: $4+4$ ya da $5+3$ ) olduğu da unutulmamalıdır.

Önemli diğer bir farklılık ise her iki programda ayrı birer öğrenme alanı olan dinleme ve konuşmanın Sözlü İletişim Öğrenme Alanı (SİÖA) olarak birleştirilip tek bir öğrenme alanı hâline getirilmesidir. Dil becerileri ile iletişim becerileri teorik olarak örtüşmektedir: Beceriler, sözlü iletişimde dinleme, konuşma; yazılı iletişimde okuma, yazma olarak sınıflandırılabilir. Bu sınıflandırma iletişim eyleminin şeklini göstermektedir. Sebep-sonuç ilişkisine dayanarak okumanın olduğu durumda yazma (yazı), dinlemenin olduğu durumda bir konuşma vardır. Bunlar, beceriler arasındaki karşılılık ilişkisini oluşturmaktadır. Sözlü iletişimde iki eylemin eş zamanlılığı, yazılı iletişime göre daha ağır basmaktadır. Bu durum dikkate alındığında, dinlemenin gerçekleşmesi için bir konuşmanın olması ve etkileşim sonucunda bu eylemlerin zincirleme devam etmesi sebebiyle 
Program'da birleştirilmesi, temel anlayış açısından, kabul edilebilir görünmektedir.

Programda, konuşma becerisinin geliştirilmesiyle; öğrencilerin, Türkçenin estetik zevkine vararak ve zengin söz varlığından faydalanarak kendilerini doğru ve rahat ifade edebilmeleri, sosyal hayatta karşılaşacakları sorunları konuşarak çözebilmeleri, yorumlayıp değerlendirebilmelerinin amaçlandığı vurgulanmaktadır. (MEB, 2015: 6) Ancak SİÖA'nın niçin oluştuğu, öğretme-öğrenme süreci, uygulama ve etkinliklerin hareket noktası, diğer öğrenme alanlarıyla ilişkisi, sınama durumları, kazanımların sınıflara hangi ölçütlere göre dağıtıldığı vs. sorularına net cevap bulunamamakta, çok kısıtlı ve muğlak, kısa ve izaha muhtaç bilgiler gelişigüzel sayılabilecek biçimde sıralanmaktadır. Kazanımların oluşturulma mantığını anlamak biraz zordur. Önceki programlarda (MEB, 2005; MEB, 2006) temel yaklaşıma dair bilgiler ve açıklamalar daha kapsamlı ve daha anlaşılır biçimde düzenlenmişti. $\mathrm{Bu}$ bilgileri yazının girişinde belirtmemizin sebebi çalışmamızın çıkış noktasını şekillendirmektedir. Çalışmanın SİÖA ile sınırlandırılmasının sebebi, yukarıda belirtilen dinleme ve konuşmanın birleştirilmesinin önemli olması ve bu öğrenme alanındaki kazanım ifadelerindeki çoğu özelliğin diğer öğrenme alanlarıyla paralellik göstermesidir. Dolayısıyla Programın genelini çalışma konusu yapmak yerine bir öğrenme alanının daha derinlemesine değerlendirme imkânından yararlanılmak istenmiştir.

$\mathrm{Bu}$ çalışmanın amacı Türkçe Dersi Öğretim Programı'nda SïÖA'daki kazanımları değerlendirmektir. Öğretim programlarının hazırlanmasındaki ve dil becerilerinin doğasındaki bütüncül bakış açısı ile bu öğrenme alanından hareketle genel bir değerlendirmeye de ulaşabilmektir.

\section{YÖNTEM}

$\mathrm{Bu}$ çalışmada nitel araştırma tekniklerinden doküman incelemesi kullanılmıştır. Türkçe Dersi Öğretim Programı'nın genel olarak değerlendirilmesinde ve SİÖA'daki kazanımların değerlendirilmesinde, eleştirel bir bakışla sunulmasında özcü yaklaşım benimsenmiştir. “Özcü yaklaşımdaki değerlendiriciler, eğitim programını bağımsız olarak incelerler. Değerlendirme ölçütleri genellikle işlevsel biçimde belirlenmez. Buna karşılık değerlendiriciler sadece 'eğitim programı ne kadar iyi?' sorusuna cevap bulmaya çalışırlar. Özcü değerlendiriciler, programda yer alan belirli bir içerik, içeriğin sıralanmasında takip edilen yol, doğruluğu, içerik ile ilgili önerilen yaşantı çeşitleri ve kullanılan materyal türleri üzerinde çalışırlar" (Ornstein ve Hunkins, 2014: 403). Alanyazınından hareket ederek gerekli durumlarda önceki öğretim programları, ortaöğretim programı ile karşılaştırmalardan yararlanılmıştır. Elde edilen bulgular yorumlanarak raporlaştırılmıştır.

\section{BULGULAR VE YORUMLAR}

Bulgu ve yorumların sunulmasında her kazanım için bir açıklama yapılma gereği duyulmamış, öne çıkan durumlar, sorunlar işlenmiştir. Kazanımların birbiriyle ilgileri, bağlantıları ölçüsünde ortak ve genel bir çerçeve sunulmak istenmiştir. Çalışma, özcü değerlendirme yaklaşımına uygun biçimde tasarlandığından bu bölümde bulgu, yorum, tartışma ve öneri birlikte sunulmuştur.

\subsection{Kazanımların Sınıflara Dağılımı}

Program'da yer alan tablo, kazanımların ard1şıklığını açık biçimde göstermede yetersiz kaldığı için sınıf düzeylerine ilişkin bir çözümlemeye ihtiyaç duyulmaktadır. Bu sebeple kazanımların bu başlık altında verilmesi hangi kazanımın hangi sınıflarda işlendiğinin bir 
bakışta belirlenmesine yönelik olarak uzun bir tabloda gösterilmesi uygun bulunmuştur. SïÖA'daki bütün kazanımlar Tablo 1'de bir arada sunulduğundan madde numaraları bu çalışma için verilmiştir. Program'daki kazanımların sınıflara dağılımı Tablo 1'de sıralanmaktadir:

Tablo 1. SİÖA'daki Kazanımların Sınıflara Dağılımı

\begin{tabular}{|c|c|c|c|c|c|c|c|c|c|}
\hline \multirow[t]{2}{*}{ Sira } & \multirow[t]{2}{*}{ Kazanımlar } & \multicolumn{8}{|c|}{ Siniflar } \\
\hline & & 1 & 2 & 3 & 4 & 5 & 6 & 7 & 8 \\
\hline 1 & Dinlediği şiiri düz yazıdan ayırt eder. & $x$ & & & & & & & \\
\hline 2 & $\begin{array}{l}\text { Dinledikleri ve izlediklerinde geçen yönergeleri takip eder } \\
\text { ve uygular. }\end{array}$ & $x$ & & & & & & & \\
\hline 3 & Verilen yönergeleri takip eder ve uygular. & & $X$ & $x$ & & & & & \\
\hline 4 & $\begin{array}{l}\text { Dinlediklerinde vurgulanan sesi tanır, ayırt eder; seslerle } \\
\text { harfleri, heceleri, sözcükleri ve görselleri eşleştirir. }\end{array}$ & $\mathrm{X}$ & & & & & & & \\
\hline 5 & $\begin{array}{l}\text { Dinlediklerinde/izlediklerinde gerçek unsurları ve hayal } \\
\text { unsurlarını ayırt eder. }\end{array}$ & $x$ & $X$ & $x$ & & & & & \\
\hline 6 & Dinlediklerinde gerçek ve kurgu olanı ayırt eder. & & & & & $x$ & $x$ & & \\
\hline 7 & Metni takip ederek dinler. & $x$ & $X$ & & & & & & \\
\hline 8 & $\begin{array}{l}\text { Dinledikleri/izledikleri ile ilgili günlük hayattan örnekler } \\
\text { verir. }\end{array}$ & $\mathrm{X}$ & & & & & & & \\
\hline 9 & Dinlerken/izlerken vurgu, tonlama ve telaffuza dikkat eder. & & $x$ & & & & & & \\
\hline 10 & $\begin{array}{l}\text { Basit resimlerden anlamlar çıkarır ve bunları birbirine bağ- } \\
\text { layarak bir olayı açılar. }\end{array}$ & & $X$ & & & & & & \\
\hline 11 & $\begin{array}{l}\text { Dinlediklerini zihninde canlandırarak olayın nasıl gelişece- } \\
\text { gini ve sonucunu tahmin eder. }\end{array}$ & & $x$ & $\mathrm{x}$ & $X$ & & & & \\
\hline 12 & $\begin{array}{l}\text { Konuşmacının sözlü olmayan (jest, mimik ve beden dili vb.) } \\
\text { mesajlarını anlar. }\end{array}$ & $x$ & $X$ & $x$ & $X$ & & & & \\
\hline 13 & Dinlediklerini/izlediklerini ön bilgileriyle karşılaştıır. & & & & & $x$ & & & \\
\hline 14 & $\begin{array}{l}\text { Dinlediklerini/izlediklerini özetler (Dinledikleri ve izlediklerin- } \\
\text { deki önemli ve önemsiz noktalar belirleme ve önemli noktalar } \\
\text { birleştirmeye yönelik çalışmalar yaptırllır). }\end{array}$ & & & & & $x$ & & & \\
\hline 15 & $\begin{array}{l}\text { Dinledikleriyle/izledikleriyle ilgili görüşlerini mantıksal sıra } \\
\text { içerisinde açıklar. }\end{array}$ & & & & & $x$ & $x$ & & \\
\hline 16 & Dinlediklerinin/izlediklerinin konusunu belirler. & $x$ & $x$ & & & & & & \\
\hline 17 & $\begin{array}{l}\text { Dinlediklerinin/izlediklerinin konusunu ve ana fikrini/ana } \\
\text { duygusunu belirler. }\end{array}$ & & & $x$ & $X$ & & & & \\
\hline 18 & $\begin{array}{l}\text { Dinlediklerindeki/izlediklerindeki ana fikri/ana duyguyu } \\
\text { belirler. }\end{array}$ & & & & & $x$ & & & \\
\hline 19 & $\begin{array}{l}\text { Dinlediklerindeki/izlediklerindeki ana fikri ve ana fikri des- } \\
\text { tekleyen düşünceleri belirler. }\end{array}$ & & & & & & $X$ & $\mathrm{x}$ & $x$ \\
\hline 20 & $\begin{array}{l}\text { Dinlediklerindeki/izlediklerindeki bilgi ve düşüncelerin } \\
\text { tutarlılığını sorgular. }\end{array}$ & & & & & & $X$ & $x$ & \\
\hline 21 & $\begin{array}{l}\text { Dinledikleri/izledikleriyle ilgili çıkarımlar yapar ([ } \underline{\text { Așamal }} \\
\text { olarak] neden-sonuç, amaç-sonuç, karşılaştırma, benzetme, örnek- } \\
\text { lendirme, duygu belirten ifadeler, abartma, nesnel ve öznel çıka- } \\
\text { rimlar vb. üzerinde durulur). }\end{array}$ & & & $x$ & $X$ & $x$ & $x$ & $x$ & \\
\hline 22 & $\begin{array}{l}\text { Dinlediği/izlediği bir metnin, medya içeriğinin veya sözel } \\
\text { sunumun örtülü anlamın belirler. }\end{array}$ & & & & & & & & $\mathrm{x}$ \\
\hline 23 & $\begin{array}{l}\text { Dinlediği konuşmada öne sürülen düşüncelerin gerekçeleri- } \\
\text { ni ve kanıtlarını belirler, sorgular ve değerlendirir. }\end{array}$ & & & & & & & & $\mathrm{X}$ \\
\hline 24 & Dinlediği konuşmada öne sürülen düşüncelerin gerekçeleri- & & & & & & & $x$ & \\
\hline
\end{tabular}


ni ve kanitların belirler (Öne sürdü̆̈̈̈ düşüncelerle ilgili verileri, destekleyici bilgileri, gerekçeleri, kanıtları ve örnekleri kullanarak görüşlerini tutarlı bir şekilde ifade etmesi sağlanır).

Dinlediği/izlediği bir okuma metni, sözel sunum veya medya içeriği hakkında sorular sorar ve sorulan sorulara cevap verir.

Konuşmacının tezlerinden ve görüşlerinden hangilerinin gerekçeler ve kanitlarla desteklendiğini, hangilerinin desteklenmediğini ayırt eder. Konuşmadaki/tartışmadaki farklı bakış açılarını fark eder. Tanıdığı kişileri, yerleri, bildiği olayları anlatır ve bunlarla ilgili düşünce ve duygularını ifade eder (Olayları oluş sırasına göre anlatması să̆lanır). Düşüncelerini ve duygularını daha iyi ifade edebilmek için uygun yerlerde çizimler, resimler vb. görselleri kullanır. Konuşmasını/sunumunu bilgiyi daha net aktarabilmek için uygun durumlarda grafikler, görseller ve benzeri çoklu medya araçları ile destekler.

Bir masalı veya olayı ana hatlariyla anlatır (Masallar veya metinlerle birlikte resimler vb. görselleri kullanarak bir olayl, düşünceyi ve duyguyu ifade etmesi sağlanır). Bir masalı, hikâyeyi, olayı ve durumları ana hatlarıla anlatır.

Okunan bir metni, medya içeriğini veya sözel sunumu kendi ifadeleriyle anlatır.

34 Konuşmasını konuya, ortama ve konuşmayı yapacağı kişi veya gruba göre uyarlar.

35 Topluluk önünde konuşur.

36 Hazırlıklı konuşma yapar (Topluluk önünde konuşulacak/tartışlacak konu için hazırlık yapması; gerekli metinleri okuyarak veya çalışarak gelmesi, konuşmasını edindiği bilgiler üzerine kurgulaması, prova yapması ve sunması sağlanır).

Hazırlıklı konuşma/sunu yapar (Topluluk önünde konuşulacak/tartışlacak konu/sunu için hazırlık yapması; gerekli metinleri okuyarak veya çalışarak gelmesi, konuşmasını edindiği bilgiler üzerine kurgulaması, konu ile ilgili kanıtlara atıflar yapması, prova yapması ve sunması săglanır).

38 Kısa bir hikâyeyi, masalı, olayı ve durumu dramatize eder.

39 Farklı türdeki metinleri dramatize eder.

40. Yabancı dillerden alınmış, dilimize henüz yerleşmemiş kelimelerin Türkçelerini kullanır.

41 Akranlarıyla ve yetişkinlerle bir konuyu konuşur/tartışır.

41.1 Göz teması kurarak işitilebilir bir ses tonuyla konuşur.

41.2 Konuşmalarında kelimeleri doğru telaffuz eder.

41.3 Tonlama ve vurgulara dikkat ederek, akıcı ve anlaşılır bir dille konuşur.

41.4 Düşüncelerini ve duygularını ifade eden, seviyesine uygun cümleler kurar.

41.5 Düşüncelerini ve duygularını ifade eden cümleler kurar.

41.6 Konuşmada/tartışmada ifade edilen fikirleri toparlar, konuşmalardan ne anladığını ve kendi düşüncelerini ifade

$$
x^{x}
$$

$\begin{array}{llllll}X & X & X\end{array}$

$x \quad x \quad x$

$X \quad X \quad X$

$x$

\section{X}

X

X

$\begin{array}{llll}X & X & X\end{array}$

X $\quad X$

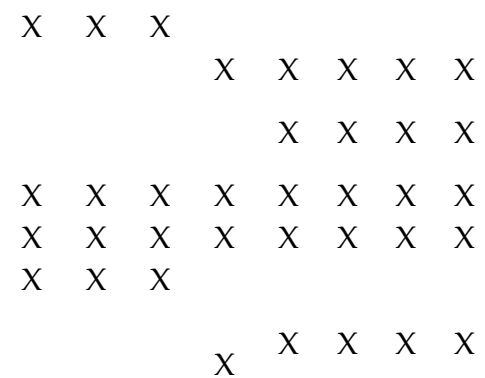

$x \quad x$ 
eder.

41.7 Konuşmada/tartışmada ikna edici ve yönlendirici ifadeleri belirler.

41.8 Konu dışına çıkmadan önceden belirlenmiş kurallara uyarak konuşur. (Başkaların dinleme, konuşmasında uygun hitap ifadeleri kullanma, başkalarının sözünü kesmeme, konuşmanın bitmesi$x \quad X$ ni bekleme, akış içinde söz alarak konuşmaya katılma vb.)

41.9 Konu dışına çıkmadan, önceden belirlenmiş kurallara uyarak konuşur/tartışır. (Başkalarımı dinleme, konuşmasında uygun hitap ifadeleri kullanma, başkalarının sözünü kesmeme, konuşmanın bitmesini bekleme, akış içinde söz alarak konuşmaya katılma $v b$.

41.10 Konuşmasında uygun hitap ifadeleri ve nezaket sözcükleri kullanir.

41.11 Konuşmanın akışı içinde sorular sorar ve sorulara cevap verir.

41.12 Konuşmada/tartışmada ifade edilen görüşleri ve bilgileri dikkate alarak kendi görüşlerini gerekçelendirir.

$\mathrm{X}$

$$
\begin{array}{ccccc}
X & X & & \\
X & X & X & X & X
\end{array}
$$

$X$
Programdan elde edilen tabloya göre sinıf seviyelerine düşen kazanım sayıları şöyledir: Birinci sınıfta 17, ikinci sınıfta 18, üçüncü sınıfta 16 , dördüncü sınıfta 15 , beşinci sınıfta 17 , altınc1 sinıfta 18, yedinci sinıfta 16, sekizinci sınıfta 16 kazanım bulunmaktadır. Sayısal olarak dengeli sayılabilecek bir dağılım sergilenmektedir. Toplam 53 kazanımdan göreceli olarak 25'i dinleme, 18'i konuşma temellidir. Etkileşmeyle ilişkilendirilebilecek kazanım sayısı ise 10 'dur. Bu sayısal bilgilerin Program'da belirtilmemesi, kazanımların sınıflara dağılımının açık biçimde gösterilmemesi işlevsellik yönünden dikkat çekici bir eksikliktir. Program'da kazanımlar sıralandıktan sonra bir tabloda aynı biçimde gösterilmesi yerine sınıf düzeylerine göre dağılımın, kullanışlılık açısından, 2005 Programı'ndaki (1-5. Sınıflar) gibi ve bu çalışmadaki Tablo 1'e benzer biçimde düzenlenmesi gerekir.

2005 Programı'nda dinleme/izleme öğrenme alanında toplamda 54, konuşma öğrenme alanında 56; 2006 Programı'nda; iki alanda 42'şer kazanım bulunmaktadır. Önceki programlarda iki öğrenme alanı ve 1-5; 6-8. sınıflardaki kazanımlar birleştirildiğinde 80 'den fazla kazanım elde edilebilir. Yeni programda bu sayının daha az olmasının iki önemli sebebi vardır: Önceki programlardaki kurallara uyma, alışkanlık kazanma, değerlendirme amaçlarını ihtiva eden kazanımların azaltılması veya bunlara yer verilmemesi birinci sebeptir. İkincisi önceki programlarda ayrı ayrı ifade edilen kazanımların birleştirilmesidir.

\section{2. Çekirdek Kazanımlar}

SïÖA'da, her sınıfta olan diğer bir deyişle açıkça belirtilebilen, çekirdek kazanım olarak nitelendirilebilecek iki kazanım bulunmaktadır: "Akranlarıla ve yetişkinlerle bir konuyu konuşur/tartışır.", "Göz teması kurarak işitilir bir ses tonu ile konuşur." İlki alışkanlığı ifade etmesi, ikincisi de bir eksikliği gidermesi bakımından konuşmanın tamamlayıcısıdır. Konuşmanın davranışsal yönüyle ilgili bu iki kazanımın her sinffa istisnasız olarak yer alması kabul edilebilir. Ancak diğer kazanımlar düşünüldüğünde -özellikle dinlemeyle ilgili olanlar- başka çekirdek kazanımlara da yer verilmesi gerekmektedir.

İletişimde göz teması karşılıklı ve etkileşimlidir. Dolayısıyla konuşmadakine benzer bir 
ifade dinleme/izlemede de olmalıdır. Dinlemede göz temasıyla ilgili bir ifadeye yer verilmemiştir. Programda sayısal olarak dinleme metinlerine çokça yer verildiği dikkate alındığında dinleme/izleme ile ilgili etkinliklerin daha çok metin temelli yapılacağına işaret etmektedir. $\mathrm{Bu}$ nedenle program hazırlayıcıları dinleme/izlemedeki göz temasını kazanım olarak ifade etmemiş olabilir. Ancak "Dinlerken/izlerken göz teması kurar.", "İletişimde göz teması kurar.", "Dinlerken/izlerken ve konuşurken göz teması kurar." anlamlarına gelecek bir kazanımın bulunmaması program hazırlayıcılarının dinleme/izleme-konuşmanın birleştirilmesine dayanak teşkil edecek önemli ve gerekli bir bilgiyi göz ardı ettiklerini göstermektedir.

Birbirini tamamlayacak şekilde tasarlanmış olan iki kazanım ifadesi ise canlandırmayla ilgilidir: "Kısa bir hikâyeyi, masalı, olayı ve durumu dramatize eder." (1.-3. sinıflar), "Farklı türdeki metinleri dramatize eder." (4.-8. siniflar). Dramatize etme de çekirdek bir kazanım olarak yer almaktadir.

Topluluk önünde konuşmayı (hazırlıklı konuşma ve tartışma) ihtiva eden üç kazanım, bitişik biçimde her sınıfta yer almaktadır. Her sınıfta kazanım olarak yer alması gerektiğini göreceli olarak- düşünebilecek birkaç kazanım şunlardır:

"Dinlediklerini/izlediklerini ön bilgileri ile karşılaştırır.": İletişimin doğası dikkate alındığında aslında bu kazanım “Dinlerken/izlerken karşılaştığı bilgileri/ olguları ön bilgileri ile karşılaştırır." şeklinde ya da buna benzer ("-ken..." ile ifade edilebilecek) şekilde bir kazanım olmalıdır (bk. Karadağ, 2012). Ayrıca anlam kurmanın önemli bir işlemi ön bilgileri ile karşılaştırmadır. Dinleme/izleme bir anlama becerisi olduğuna ve anlam ön bilgiler üzerine yapılandırıldığına göre bunu ifade eden bir kazanımın her sınıf düzeyinde yer alması gerektiği düşünülebilir.

"Dinlediklerini/izlediklerini özetler.": Buna sadece 5. sinıfta yer verilmiştir. Program'ın genel düzeninden anlaşıldığı kadarıyla bu kazanım 5 . sınıftan itibaren başlamaktadır. Özetleme zihni yapılandırmada önemli bir bilişsel özelliktir. Daha önceki ve sonraki sınıflarda da çekirdek bir kazanım olarak yer verilmesi beklenebilir.

"Konuşmalarında kelimeleri doğru telaffuz eder.": Türkçe dersinde gerek dinleme ve konuşmada (sözlü iletişim) gerekse okumada kelimenin doğru telaffuz edilmesi hususunda sınıf ayrımı gözetilmemelidir. Bu durum, bu üç dil becerisinin, daha doğrusu, anlama ve anlatma becerilerinin temel unsurudur. Bu kazanım sadece ilk üç sınıfta yer almaktadır. Diğer sınıflarda “Tonlama ve vurgulara dikkat ederek, akıcı ve anlaşılır bir dille konuşur." kazanımı bulunmaktadır. Bitişik bir kazanım olarak değerlendirilebilir. Ancak öğrenciler eğitimleri boyunca okul içinde ve dışında birçok kelimeyle karşılaşırlar. Bunları edinme sürecinde kelimenin telaffuzu da önemlidir. Devamındaki akıcılıkla ilgili kazanımin vurgu, ton ile birlikte telaffuzu kapsayıp kapsamadığı teknik konulardır, tartışmalıdır. Ayrıca akıcı konuşma da akıcı okuma kadar önemlidir. Program'da akıcı okuma ile ilgili her sınıfta birden çok kazanım vardır. Program'da akıcı konuşmayla ilgili bir ifadenin çekirdek kazanım olarak yer alması, akıcı okumayı desteklemesi açısından önemlidir.

\subsection{Binişik İfadeler}

Programlamada kazanımlar, binişik değil, bitişik olmalı; kazanımların biri, diğerinin kapsamina girmemelidir. İfadeler tek bir önerme/yargı şeklinde olmalıdır (Büyükkaragöz, 1997; Demirel, 2000). Önceki programlarda (MEB, 2005; MEB, 2006) tek bir yarg1 bildiren, bir işlem yapıldığ belli olan kazanım ifadelerinin çokluğu dikkat çekmektedir. Yeni prog- 
ramda SİÖA'da tek yargı bildiren ifadelerin sayısı azdir.

"Dinlediklerinde vurgulanan sesi tanır, ayırt eder; seslerle harfleri, heceleri, sözcükleri ve görselleri eşleştirir." kazanımı ses-göz ilişkisini kurmaya, ilkokuma-yazmayı öğrenmeyi desteklemek için SíÖA'ya yazılmış olabilir. Bu kazanımda sesi tanıma ve ayırt etme bir işlemdir. Seslerle harf, hece, sözcük; görseli eşleştirme ayrı bir bilişsel işlemdir. Ayrıca öğrencinin sesle ilgili üç unsuru (harf: sembol, hece: parça, sözcük: birim) ve görsel ile eşleştirmesi istenmektedir. Toplam altı bilişsel işlemin tek bir kazanımda ifade edilmesi, ilkokuma-yazmayı destekleme açısindan önemli bir hata olarak görülebilir.

Birden fazla yargı bildiren kazanımlar şunlardır: "Basit resimlerden anlamlar çıkarır ve bunları birbirine bağlayarak bir olayı açıklar.", "Dinledikleri ve izlediklerinde geçen yönergeleri takip eder ve uygular.", "Verilen yönergeleri takip eder ve uygular.", "Dinlediklerinin/izlediklerinin konusunu ve ana fikrini/ana duygusunu belirler.", "Dinlediklerindeki/izlediklerindeki ana fikri ve ana fikri destekleyen düşünceleri belirler.", "Dinlediği konuşmada öne sürülen düşüncelerin gerekçelerini ve kanttlart$n$ belirler, sorgular ve değerlendirir.", "Dinlediğilizlediği bir okuma metni, sözel sunum veya medya içeriği hakkında sorular sorar ve sorulan sorulara cevap verir.", "Tanıdı̆̆ $\imath$ kişileri, yerleri, bildiğ $i$ olayları anlatır ve bunlarla ilgili düşünce ve duygularını ifade eder.", "Yabancı dillerden alınmıs, dilimize henüz yerleşmemiş kelimelerin Türkçelerini kullanır.", "Göz teması kurarak işitilebilir bir ses tonuyla konuşur.", "Konu dışına çıkmadan, önceden belirlenmiş kurallara uyarak konuşur.", "Konu dışına çıkmadan, önceden belirlenmiş kurallara uyarak konuşur/tartışır.", "Konuşmanın akışı içinde sorular sorar ve sorulara cevap verir.", "Konuşmada/tartışmada ifade edilen fikirleri toparlar, konuşmalardan ne anladığını ve kendi düşüncelerini ifade eder."
Kazanımlar karşılaştırıldığında önceki programlarda (MEB, 2005; MEB, 2006) konu, ana fikir ve yardımcı fikir ayrı ayrı ele alınmış ve üç ayrı kazanım yazılmış iken yeni programda binişik hâle getirilmiştir (konu; konu ve ana fikir; ana fikir ve destekleyici fikir ). Bu üç bilişsel işlemin tek bir kazanım çatısında birleştirilmesi ölçme ve değerlendirme uygulamaları açısından sakıncalar doğurabilmektedir. Çünkü uygulamada, doğasında bireysel farklılar taşıyan öğrencilerden bazıları dinlediği bir metnin konusunu bulsa bile ana fikri ifade edemeyebilir. Bazıları ana fikri bulsa da yardımcı fikirleri tespit edemeyebilir. Tek bir kazanım altında birleştirilmesi öğrenme-öğretme sürecinde bu becerilerin ve gelişme düzeylerinin saptanmasını engelleyici bir olgu hâline getirebilir. Bunun, teorik olarak, öğrencinin zihni yapılandırılmasında bir sorun oluşturabileceği göz ardı edilmemelidir. Bu binişiklik, bitişikliğe dönüştürülmelidir: "Dinlediklerinin/izlediklerinin konusunu belirler.", "Dinlediklerinin/izlediklerinin ana fikrini/ana duygusunu belirler.", "Dinlediklerindeki/izlediklerindeki destekleyici fikirleri/yardımcı duyguları belirler." Üç kazanımın birleştirilmesi, konu belirleme ile ilgili kazanımların üst sınıflarda yer almaması; konu, ana fikir, yardımcı fikirler üçgeninde 1981 kazanımlarına dönüldüğünü gösterebilir (MEB, 2000): “Dinlediği, izlediğ $i$ bir

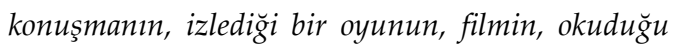
bir yazının, ana fikrini, yardımo fikirlerini kavrayabilmek"...

"Akranlarıla ve arkadaşlarıla bir konuyu konuşur/tartışır." (Bu kazanımın altındaki 12 kazanım dâhil), “Topluluk önünde konuşur.”, "Hazırlıklı konuşma yapar.", "Hazırlıkl konuşma/sunu yapar." kazanımları birbirinin kapsamına giren binişik kazanım ifadeleridir.

Kazanımlar arasında binişiklik az olmasına rağmen bir kazanımın birden çok yargıyla ifade 
edilmesi önemli bir sorun olarak değerlendirilebilir.

\subsection{Ardışıklık}

Ardışıklık, öğretim programındaki konuların dikey ilişkilerle düzenlenmesini gösterir. Öğrenme konularının ya da beceri geliştirici konuların sürekliliğini sağlamak için koşullu ya da tekrarlı yani sarmal yaklaşımlı bir düzenlemeyi gerektirir. SİÖA'daki bazı kazanımların sınıflara göre dağılımında sürekliliği ve yapılandırmayı sağlayan ardışıklık bağlantılarının kurulup kurulmadığı şu örneklerle irdelenebilir:

1-3. sinıfta "Dinlediklerinde/izlediklerinde gerçek unsurları ve hayal unsurlarmı ayırt eder." kazanımı yer almaktadır. Bunun devamındaki ilişkili "Dinlediklerinde gerçek ve kurgu olanı ayırt eder."11 kazanımı 5 ve 6. sinıfta yer almaktadır. Ancak 4. sınıfta gerçek ve gerçek olmayanı ayırt etmekle ilgili bir kazanımın bulunmaması bu ilişki bağını sekteye uğratmaktadır.

Dinleme/izleme temelli "Dinlerken/izlerken vurgu, tonlama ve telaffuza dikkat eder." kazanımı sadece ikinci sınıfa özel bir kazanımdır. Dinleme/izleme temelinde öncesi ve sonrası yoktur ${ }^{* 2}$. Vurgu, tonlama ve telaffuzla ilgili unsurlar, öğrencide dikkatli dinleyerek, iyi gözleyerek birikimli bir süreç sonunda elde edilir ve kullanılmaya hazırlanır. Bu kazanımın süreksizliği dikkat çekici bir eksikliktir. Vurgu ve ton unsurlarının konuşmayla ilgili olan kısmı “Tonlama ve vurgulara dikkat ederek, akıcı ve anlaşılır bir

\footnotetext{
${ }^{11} \mathrm{Bu}$ kazanımda "izlediklerinde" ibaresinin ifadede yer almaması öğrenme alanının bütünlüğü bozmaktadir.

*2 Birinci sınıfta kelimeyle ya da konuşmayla değil, daha çok sesle ilgili binişik bir ifade olan "Dinlediklerinde vurgulanan sesi tanır, ayırt eder; seslerle harfleri, heceleri, sözcükleri ve görselleri eşleştirir." kazanımı ile sözü geçen kazanım arasındaki ilişki güçlü değildir.
}

dille konuşur." kazanımı ise 4-8. sınıflarda yer almakta ve süreklilik sergilemektedir.

"Konuşmacının sözlü olmayan (jest, mimik ve beden dili vb.) mesajlarm anlar.", 1-4. sinifta yer almakta olup sonrasında (5-8. sınıf) işlenmeyen bir kazanımdır. Anlamanın doğasında olan bu durum, ardışıklığı ve bütünlüğü bozmaktadır.

"Dinlediğilizlediği bir okuma metni, sözel sunum veya medya içeriği hakkında sorular sorar ve sorulan sorulara cevap verir." (2-4. sinuflar), "Konuşmanın akışı içinde sorular sorar ve sorulara cevap verir." (4-8. sinıflar) kazanımları soru sormayla ve cevap vermeyle ilgilidir. İki kazanım, 4. sınıfta bir arada işlenmektedir. Kazanımlardan ilki dinleme/izleme temelli, ikincisi konuşma temelli olsa da iletişimi ihtiva eder. Dinleme/izleme ve konuşma ilişkisinde birbirini tamamladıkları söylenebilir. Soru sorma ve cevap verme etkileşimli bütün derslerde geçerli bir öğrenme-öğretme faaliyetidir. İki kazanım da çekirdek kazanım olarak değerlendirmeye alınıp 1-8. sınıflarda yer alması gerektiği düşünülebilir.

"Dinledikleri/izledikleri ile ilgili günlük hayattan örnekler verir." kazanımı sadece 1. sınıfta geçmektedir, bu yönüyle sonrasız ve süreksiz bir kazanımdır. Kanaatimizce Türkçe dersiyle ilgili olarak ilkokuma ve yazma kazanımları ilköğretim 1. sınıfa özgü kazanımlar olarak değerlendirilmelidir. Öğrencilerin dinleme/izleme yoluyla anlam kurmalarında ön bilgilerini harekete geçirerek günlük hayatla bilgi ya da örnek vermeleri bilişsel, duyuşsal gelişimleri açısından da önemlidir. Dolayısıyla bu kazanımın sürekliliğin daha fazla olması gerekir.

Öncesi ve sonrası olmayan iki kazanım ifadesi 5. sınıfta dikkat çekmektedir:

"Dinlediklerini/izlediklerini özetler.": Bu ifade "hangi kazanımla bağlantılı olabilir?" diye düşünüldüğünde 2. ve 3 . sınıftaki ana hatları ile anlatmayla ilgili kazanımlar ve 4 . sinıfta 
kendi ifadeleriyle anlatma kazanımları ile ilişkilendirilebilir. Bu kazanımlarla ilgili bağlantı, özetleme bağlamında kuvvetli görünmemektedir. Özetleme, anlam kurmada genelleştirme ve değerlendirme gibi bilişsel işlemleri güçlendiren bir beceridir ve sarmallık bakımından 5 . sınıftan önce başlaması, süreklilik taşıması gereken bir kazanım olmalıdır. "Dinlediklerinilizlediklerini ön bilgileriyle karşılaştırır." kazanımında belirtilen "ön bilgileriyle karşılaştırma" anlama ve öğrenmenin temelini oluşturan bilişsel bir işlemdir. Dolayısıyla 5. sınıftan önce başlaması ve sürekliliğin olması gerektiği düşünülebilir.

1-3. sinıflarda "Konu dışına çıkmadan, önceden belirlenmiş kurallara uyarak konuşur." ifadesine 4. sınıfta ardışıklığı göstermek adına “...tartışır" yargısı eklenerek ikinci bir kazanım elde edilmeye çalışılmıştır. Oysa çekirdek kazanım olan "Akranlarıla ve yetişkinlerle bir konuyu konuşur/tartışır." 1'den 8'e bütün sınıflarda yer almaktadır.1. sınıftaki bir öğrenciye tartışma kazanımı verilmeye çalışırken "konu dışına çıkmama ve kurallara uyma" ilkeleri üstüne yapılandırılmak istenmiştir. Bu ilişkiler bağlamında kazanım ifadelerinin belirsizliği, iki kazanımın binişikliği ve birinin sürekliliği, diğerinin süreksizliği çapraşık ve hatalı kazanımlar yazılmasına neden olmaktadır. Bu tür ifadeler programdaki kazanım anlayışının karmaşık ve anlaşılmasının zor olduğunu göstermektedir.

1-3. sınıflarda "Düşüncelerini ve duygularını ifade eden, seviyesine uygun cümleler kurar." ifadesinden "...seviyesine uygun..." ibaresi atılarak 4. sınıf için yeni bir kazanım elde edilmek istenmiştir: "Düşüncelerini ve duyguların ifade eden cümleler kurar." Bu kazanım, 4. sınıftaki öğrencinin seviyesinin altında ya da üstünde cümle kurmasının işareti midir? 1-3. sınıf öğrencileri seviyesinin altında ya da üstünde cümle kurmaları bu kazanımın yazılması için gerekli midir? İzaha muhtaç bir ardışıklık ilişkisi söz konusudur.

SİÖA'da konu, ana fikir ve yardımcı fikir belirlemeyle ilgili şu kazanımlar bulunmaktadır: "Dinlediklerinin/izlediklerinin konusunu belirler." $(1,2$. siniflar), "Dinlediklerinin/izlediklerinin konusunu ve ana fikrinilana duygusunu belirler." (3, 4. sinıflar), "Dinlediklerindeki/izlediklerindeki ana fikrilana duyguyu belirler." (5. sinif), "Dinlediklerindeki/izlediklerindeki ana fikri ve ana fikri destekleyen düşünceleri belirler." (6, 7, 8. sinıflar). $\mathrm{Bu}$ kazanımların dağılımı önceki programlarla (MEB, 2005; MEB, 2006) karşılaştırıldığında konu belirleme her sinıfta, ana fikir belirleme 28. sıniflarda, yardimcı fikir belirleme 4-8. sinıflarda kazanım olarak yer almaktaydı. Yeni programda konu, ana fikir, yardımcı fikirlerle ilgili işlemlerin daha uzun bir süreye yayılarak aralarındaki açık ve güçlü bağlantıların fark edilmesini, edinilmesini güçleştirmektedir. Önceki programlarda belirli bir sınıfta başlayan buna benzer kazanımlar süreklilik gösterirken yeni programda belirli bir sınıfta başlayan kazanım bitmekte, bir sonra yapılacak işlem basamağına geçilmektedir. Oysa konu, ana fikir, yardımcı fikirleri belirleme sırayla yapılan ve anlam kurmada çok önemli olan işlemlerdir. Konu belirleme kazanımı, bir sonraki öğretim basamağında öğrencinin karşılaşacağı yeni Türk Dili ve Edebiyatı Dersi (9, 10, 11, 12. Sınıflar) Öğretim Programı'nda “Dinlediği konuşmanın konusunu ve ana fikrini tespit eder." şeklinde belirtilmektedir. 5-8. siniflarda adi anılmayan konu belirleme, 9-12. sinıflarda tekrar kazanımlaştırıldığına göre bu durum ilköğretim programında bağlantıların iyi kurulamadığı söylenebilir. Konu belirleme ile ilgili kazanım diğerlerini de etkilediği için çekirdek kazanım olarak 1-8. sinıflarda yer verilebilir.

Program'ın giriş kısmında verilen örneğin dişında, 4-7. sinıflarda geçen “Кonuşmadaltartışmada ifade edilen fikirleri toparlar, konuş- 
malardan ne anladığımı ve kendi düşüncelerini ifade eder." ve 8. sinifta yer alan "Konuşmada/tartışmada ifade edilen görüşleri ve bilgileri dikkate alarak kendi görüşlerini gerekçelendirir." kazanımlarındaki ardışıklık ve bitişiklik açısından SİÖA'daki nitelikli kazanım örnekleri olduğunu belirtmekte yarar vardır.

\subsection{Muğlak İfadeler}

SíÖA'daki kazanım ifadelerinden bazıları anlamada güçlüğe, karışıklığa ve belirsizliğe sebep olmaktadır:

"Metni takip ederek dinler." kazanıminda bir ifade yanlışlığı sebebiyle hemen hemen her sözcüğün anlamlandırılmasında muğlaklık söz konusudur. Bu kazanım SİÖA'da yazıldığına ve konuşulanlar da metin olduğuna göre burada anlatılmak istenenin "Bir konuşmayı takip eder/dinler." olması gerektiği düşünülebilir. Ancak bu kazanım ifadesi, program hazırlayıc1larının amacının sesli okumayla ilişkilendirmeye çalıştıklarını sezdirmektedir. Yani birisinin okuduklarını, yazılı metinde kelime ve cümleleri gözüyle takip etmeyi kastetmiş olabilirler. Sesli okumada öğrenci önce sesi duyar sonra satırlara bakar. Elbette işitme ve takip etme işi eş zamanlı yapılır ve bu durum -ArAk eki kullanılarak anlatılır. Ancak önce başlayan işitmedir. Bunu dikkate alarak kazanım için "Dinlediği metni gözüyle takip eder.", "Metni dinleyerek takip eder.", "Metni dinlerken yazıy1 takip eder." vs. birçok seçenek ifadesi bulunmaktadır. Ayrıca bu kazanım 1. ve 2. sınıfta yer aldığ1 düşünüldüğünde ve sesli okumadan bahsedildiği varsayıldığında dinleme yerine belki de işitme ifadesinin konularak "İşittiklerini yazılı metinde takip eder." şeklinde ifade edilmesi daha doğru olabilirdi. Sonuçta bu kazanımın yazılmasında birçok seçenek içinde anlam muğlaklığına sebep olan bir seçenek tercih edilmiştir.
Kafa karıştıran başka bir kazanım ifadesi de şudur: "Okunan bir metni, medya içeriğini veya sözel sunumu kendi ifadeleriyle anlatır." Okunan bir metinden "sesli okuma" sonucu dinleme/izleme, medya içeriğinden "ekrandan [okuma], video izleme, kayit dinleme vs.", sonucu dinleme/izleme, sözel sunumdan "başkasının konuşması" sonucu dinleme/izleme anlaşılmaktadır. Kazanımın -buraya kadarki kısmı- ifadesi karmaşıktır. Bu sayılanları karşılayan ve diğer dinleme/izleme kazanımlarında tercih edilen "dinlediklerini/izlediklerini" ifadesi karmaşıklığı önleyebilir. Yani kazanım "Dinlediklerini/izlediklerini kendi ifadeleriyle anlatır." şeklinde basitleştirilebilir.

"Basit resimlerden anlamlar çıkarır ve bunları birbirine bağlayarak bir olayı açıklar." kazanımı da izaha muhtaç bir ifadedir. Bu ifadede en az iki bilişsel işlemin olmasının yanı sıra iki kazanım bulunmaktadır. Birincisi resimden anlam kurma, ikincisi resimleri arasındaki ilişkiyi bularak açıklama. Birincisi üzerinde duralım: Burada anlatılmak istenen bir konuşmada kullanılan resimler midir, medya içeriğindeki resimler midir belli değildir. İfadeden anlaşıldığı kadarıyla kazanımın derste gerçekleşmesi için resimlenmiş bir olay ya da anlatımın bulunup etkinlik düzenlemeyi gerektirir. Bu kazanım bağlamında program hazırlayıcıları dinlemede izlemenin varlığından dolayı SïÖA'ya almış olabilirler. Dinleme/izlemede seslerin ve konuşanın görüntülerinden anlam kurma, okumada ise bir görüntüden (harf, kelime, cümle, resim vs.) anlam kurma ön plandadır. Dinleme/izleme ya da konuşmadan farklı müstakil bir resme bağlı olayın açıklaması kastediliyorsa bu görsel okumadır, dolayısıyla okuma kazanımları içinde yer alması daha doğru olmalıdır. "Resim ve fotoğrafları yorumlar." şeklinde buna benzer bir kazanim 2005 programinda geçmektedir. Kazanımın öğrenme alanı ise görsel okuma ve görsel sunudur. Kazanımın ikinci kısmına gelecek olursak resimler arasın- 
daki ilişkiden hareketle bir olayı açıklar. Bu da yine aynı gerekçelerle okuma öğrenme alanını ilgilendirmektedir. Sonuç olarak bu kazanımın hem ifadesi hem de ait olduğu öğrenme alanı problemli gözükmektedir.

"Verilen yönergeleri takip eder ve uygular." şeklinde 2. ve 3. sınıfta geçen kazanım, 1. sınıftaki "Dinledikleri ve izlediklerinde geçen yönergeleri takip eder ve uygular." kazanımın devamı niteliğindedir. Bu ifadede bir belirsizlik bulunmaktadır. Yönergelerin yazılı olarak verilmesi, takibi ve uygulaması okuma ile ilişkilidir. Yönerge sözlü ise zaten birinci sınıftaki kazanım ifadesi geçerlidir.

İkinci sınıftaki kazanımlardan birisi “Bir masal veya olayı ana hatlarıla anlatır." kazanımıdır. Birinci kısımda bir metin türünden (masal) bahsedilmektedir. İkinci kısımda -muhtemelengerçekleşmiş bir hadiseden bahsedilmektedir. 1, 2, 3. sınıflardaki ortak bir kazanım da şudur: "Kısa bir hikâyeyi, masalı, olayı ve durumu dramatize eder." İkinci sınıftaki bir öğrenci bir masalı anlatabilir ama hikâyeyi anlatamaz mi? Anlatamadığı bir hikâyeyi dramatize edebilir mi? Dramatize etme sadece pandomima gibi bir şey midir? Olay, masal, hikâye; anlatma, dramatize ayrımlarındaki amaçlar nedir? Bu soruların cevabı tartışmalı da olsa bu iki kazanımın aynı sınıfta (2. sınıfta) farklı şekillerde ifade edilmesi tutarsızlık olarak yorumlanabilir. Bununla ilişkili bir ifade ise "Farklı türdeki metinleri dramatize eder." (4-8. sınıf) kazanımıdır. Öğrencilerin yaş ve sınıf seviyeleri dikkate alındığında, dramatize etme, içinde hareket olan metin türlerini ihtiva etmesi gerekir. Öğrencilerin bir öğretici türleri dramatize etmesinin zorluğu hesaba katıldığında bu ifadelerin genelleştirilmesi karmaşıklığı engelleyebilir. Örneğin kazanımlar anlatma için alt sınıflarda "Dinlediklerini/izlediklerini ana hatlarıyla anlatır.", “Okuduklarını ana hatlarıyla anlatır.", "Yaşadığı ya da şahit olduğu bir olayı ana hatlarıyla anlatır", üst sinıflarda "Dinlediklerini/izlediklerini anlatır." dramatize için "Olaya dayanan metinleri dramatize eder." şeklinde ifade edilirse hem kazanım sayısı azalmış olur hem de esnek ve daha net bir kazanım elde edilebilir.

SİÖA'daki bazı kazanım ifadelerinde öğrencinin dinleme/izleme sürecinde elde edilen bilişsel işlemlerinin sonucunda ortaya çıan duygu ya da düşüncelerin nasıl aktaracağı ile ilgili sorunlar bulunmaktadır. Örneğin "Dinledikleriyle/izledikleriyle ilgili görüşlerini mantıksal sıra içerisinde açıklar.", "Dinledikleri/izledikleri ile ilgili günlük hayattan örnekler verir.", "Dinlediklerini/izlediklerini özetler." kazanımlarında anlatmaya yönelik ifadeler kullanılmıştır. Bunlar SİÖA'da bulunduğuna göre dinlemenin karşılığında konuşmada örnek verme, özetleme anlaşılması gerekir. Bu tür kazanımlarda bilişsel unsurlar ağır bassa da davranışsal özellikler de barındırmaktadır. Davranışın ne şekilde gerçekleşmesi gerektiğiyle ilgili bir ifadenin olması kazanımı daha açık hâle getirebilir. Bu durumla ilgili olarak Özbay (2010: 43), 2006 Programı'ndaki kazanımlara göndermede bulunarak şunu önermiştir: “Okuma ve dinleme/izleme becerilerinde anlatıma yönelik ifadelerin uygun kazanımlar hâlinde konuşma becerisi ile ilgili amaç ve kazanımlar arasına konulması hususudur. Öğrencilerin okuduğundan, dinlediğinden/izlediğinden hareketle yapacağı her türlü sözlü anlatım çalışması için uygun amaç ve kazanımlar belirlenerek programa konulmalıdır." Bu tür kazanımlarda öğrencinin açıklama, örnek verme, özetleme işlerini hangi biçimde aktaracağı belli değildir. Öğrenme alanı, sözlü iletişim olduğuna göre kazanım ifadeleri “...sözlü olarak açıklar.”, , “...sözlü olarak özetler.” şeklinde bitirildiğinde hem bu sorun ortadan kalkmış hem de dinleme/izleme ve konuşma becerileri öğrenme alanının doğasına uygun şekilde birleştirilmiş olur. Örneklemeyle ilgili olarak da kazanım, 
aynı mantıkla "Konuşmasında, dinledikleri ve izlediklerinden hareketle günlük hayattan örnekler verir." şeklinde ifade edilebilir. Çünkü açıklama, örnek verme, özetleme gibi unsurlar, bilişsel işlemler sonucunda (hatırlama, eşleştirme, bağdaştırma, doğrulama, çözümleme, genelleme vs.) gerçekleştikten sonra bir şekilde söz ya da yazı ile anlatılır.

Karadağ (2012: 110) buna benzer bir sorunun 2006 Programı'nda olduğunu "Programda, anlama becerilerinin özellikleri kazanımlaştırılırken, anlatmaya yönelik ifadeler kullanılmıştır." şeklinde vurgulamıştır. Yeni programda dinleme ve konuşma SïÖA'da birleştirildiğine göre anlatmaya yönelik ifadelerin yer alması kabul edilebilir. Ancak örneğin okuma alanındaki "Hikâye, drama veya şiirde sahne veya dörtlük gibi terimleri kullanarak bir sonraki kısmm bir önceki üzerine nasıl kurgulandı̆̆ını belirtir." uzun ve karmaşık kazanım ifadesinde anlama, anlatmaya yönelik olup belirtmenin sözlü mü, yazılı mi yoksa her ikisiyle mi aktarılacağ belirsizdir. Yukarıda değinildiği gibi sözlü/yazılı olarak ifadesinin, farklı öğrenme alanına girebilen kazanımlarda, belirtilmesi daha uygun olabilir.

“Konu dışına çıkmadan, önceden belirlenmiş kurallara uyarak konuşur (Başkaların dinleme, konuşmasında uygun hitap ifadeleri kullanma, başkalarının sözünü kesmeme, konuşmanın bitmesini bekleme, akış içinde söz alarak konuşmaya katılma vb.)." şeklindeki açıklamalı kazanımda -özellikle“önceden belirlenmiş kurallara uyma” ibaresiyle ne anlatılmak istendiği tartışmalıdır. Açıklamaya bakıldığında konuşmada dikkat edilecek hususlar rastgele sıralanmıştır. “Önceden belirlenmiş" ibaresinde her konuşma için farklı kurallarla konuşma mı kastedilmektedir, genel konuşma kuralları $\mathrm{m} ı$ belli değildir. $\mathrm{Bu}$ ifade "Konuşma kurallarına uyar." şeklinde ya da "Belirli bir konu çerçevesinde konuşur." şeklinde kazanımlaştırılabilir. Kazanımın parantez içindeki çerçevesinde belirtilenlerin bir kısmı önceki programlarda müstakil birer kazanım olarak yer almaktaydı. Yeni Program'da ilk dört sınıfta parantez içinde geçen "uygun hitap ifadeleri kullanma" ibaresi beş ve altıncı sınıfta kazanımlaştırılmıştır. Program'da ölçme ve değerlendirme başlığı altında (MEB, 2015: 13) “Sözlü iletişim öğrenme alanında öğrencinin 1. sınıftan 4. sınıfa kadar aşamalı bir şekilde konuşmada temel kurallara uyma, göz teması kurarak işitilebilir bir ses tonuyla konuşma, tonlamaları ve vurguları uygun kullanma, konuya odaklanma, uygun hitap ve nezaket ifadeleri kullanma, dinlediğini aktarma, özetleme, anlamlandırma gibi becerilerinin gelişimi gözlemlenmeli, izlenmeli ve tam öğrenmenin sağlanması için öğretim sürecinde gerekli düzenlemeler yapılmalıdır." şeklindeki yönergenin yer alması, bu kazanımdaki muğlaklığın, parantez içindeki kazanıma dönük ifadelerdeki binişikliğin göstergesidir. 1-4. sınıflarda beceri olarak belirtilen kurala uyma, göz teması kurma, tonlama-vurgulama, özetleme kazanım olarak Program'da yer alırken söz konusu sınıflarda hitap etme ifadesi geçen bir kazanım bulunmamaktadır. Bu açıklamalardan program hazırlayıcılarının parantez içinde yazdıklarını da kazanım olarak değerlendirdikleri, kazanımlara bakış açılarının karmaşık olduğu söylenebilir.

Çekirdek kazanım olarak yer alan "Akranlarıyla ve yetişkinlerle bir konuyu konuşur/tartışır." kazanımında "yetişkinlerle" ifadesi sebebiyle bir alışkanlığa dönüştürülmesinin amaçlandığg sezilmektedir. Uygulama açısından sınıfta bir konuşma ya da tartışma olacaksa dışarıdan bir yetişkinin her daim getirilmesi mümkün görünmemektedir. Ayrıca öğrenci kendisinden küçüklerle bir konuyu konuşamaz mı, tartışamaz mi? Örneğin 8. sinıftaki bir öğrenci, 1. sınıftaki bir öğrenciyle, 4 yaşındaki bir öğrenciyle konuşamaması söz konusu edilemez. Kanaatimizce bu kazanım ifadesi her yönüyle 
problemlidir. Hatta gereksiz bile görülebilir. Bu kazanımı yazma zorunluluğu doğmuş ise amaç izlenimi verilmeden (madde numaralamada bir ilişki güdülmeden) ilk üç sınıfta "Başkalarıyla bir konuyu konuşur.", son beş sınıfta "başkalarıyla konuyu konuşur/tartışır." şeklinde yazılabilir.

SïÖA'daki kazanımlarda, bir amaca bağlılık söz konusu olmamasına rağmen bir amaç ya da üst-amaç izlenimi veren "Akranları ve yetişkinlerle bir konuyu konuşur/tartışır." şeklinde belirtilen kazanımına bağlı alt-kazanımlar numaramadde ilişkisi biçiminde yazılmıştır. Bu kazanımlar incelendiğinde ve irdelendiğinde başta verilen kazanımla ilişkilendirilen kazanımların, herhangi bir konuşmada dikkat edilmesi gereken hususlar olduğu anlaşılmaktadır. Örneğin 4. siniftan itibaren yazılan "Tonlama ve vurgulara dikkat ederek akıcı ve anlaşılır bir dille konuşur." ifadesi; bahçede iki öğrencinin konuşmasında, sınıf içinde herhangi bir iletişim etkinliğinde, bir panelistin topluluk önünde önünde konuşmasında, bir öğretmenin ders anlatımında olması gereken konuşmanın doğasında varolan bir unsurdur. Amaçmış gibi gösterilen kazanımin altında yazılan alt-kazanımların hepsi aynı şekildedir. Böyle bir ilişki kurulmasının mantıklı bir izahını yapmak oldukça zordur.

"Akranları ve yetişkinlerle bir konuyu konuşur/tartışır." kazanımına bağlı alt-kazanımların sinıflara göre yazılmasında da tutarsızlıklar gözlenmektedir. Örneğin 1-4. sinıflarda ortak olan "Konu dışına çıkmadan, önceden belirlenmiş kurallara uyarak konuşur/tartışır." kazanımından sonra ilk üç sınıfta başka bir kazanım yoktur. 14. sınıflarda konuşma kurallarına uymayla ilgili bu kazanımın açıklamasında "...akış içinde söz alarak konuşmaya katılma vb." ibaresi bulunmaktadır. 4. sınıftan 8. sınıfa kadar "Konuşmanın akışı içinde sorular sorar ve sorulara cevap verir." kazanımına yer verilmiştir. Önceki kazanımda belirtilen söz alarak konuşmaya ka- tılma vb.nin içinde soru sorma da olabilir. Bu durum zaten parantez içindeki açıklamada yer alan "vb." ile ifade edilmektedir. Ayrıca topluluk önünde konuşurken de sorulara cevap verilmesi bilinen bir durumdur. Buna ek olarak konuşmacı da soru sorabilir. Bir akran ya da yetişkinle konuşurken soru sormak ya da cevap vermek için ilköğretimde üç yılın geçmemesi gerekir, birinci sınıftan itibaren kazanılması gereken bir iletişim unsuru olarak görülmelidir. Sonuç olarak "Akranları ve yetişkinlerle bir konuyu konuşur/tartışır." kazanımına bağlı altkazanımların topluluk önünde konuşma ve hazırlıklı konuşma kazanımlarıyla doğrudan ilişkilidir. Bunların üst kazanıma bağlanması karmaşıklığa neden olmaktadır.

"Yabancı dillerden alınmış, dilimize henüz yerleşmemiş kelimelerin Türkçelerini kullanır." kazanımı önceki programlarda da bulunmaktaydı. Uygulamada öğrencilerin bu bilgiye dayalı davranışı sergilemelerinde güçlüklerle karşılaşılabilir. Öğrenciler ilköğretimde bir kelimenin Türkçe olup olmadığını anlamaları, Türkçeye yerleşip yerleşmediğini kavramaları oldukça zordur. Genel amacı destekleyecek bir kazanıma dönüşmesinde birçok engelin bulunduğu bu ifade, "Konuşmalarında Türkçe kelimeler kullanmaya özen gösterir." şeklinde gayret etmeyi simgeleyen bir ifadenin seçilmesi daha doğru ve gerçekçi olabilir.

Yukarıda geçen kazanımlardan bazıları, 2006 programında olduğu gibi "aşırı genelleme" (Güzel ve Karadağ, 2013) özelliği gösterdiği için belirsiz ya da farklı anlamlara ulaşmaya neden olmaktadir.

\subsection{Karşılıksızlık/Eksiklik}

SİÖA içindeki bazı unsurların birbirini etkilemesi, karşılığının olması kazanımlara yansımamaktadır. Bunlardan bazıları şöyle sıralanabilir: 
“Konuşmactnın sözlü olmayan (jest, mimik ve beden dili vb.) mesajlarmı anlar.", dinleme/izleme temelli bir kazanımdır. Bunun konuşmada karşılığını bulan bir ifadesi yoktur. Bu eksiklik, "Konuşmasında sözlü olmayan mesajlar (jest, mimik ve beden dili vb.) iletir.", "Konuşmasında beden dilini kullanır.", "Beden dilini konuşmasının ritmine göre kullanır." anlamlarına gelebilecek şekilde giderilebilir.

"Dinlediklerini/izlediklerini özetler." kazanımının karşılığı bulunmamaktadır. "Konuşmasını özetler.”, “Kendi konuşmasını özetler.”, “Sunumunda/sunumun sonunda anlattıklarını özetler." anlamına gelecek bir kazanıma yer verilebilir.

Konuşma temelli "Yabancı dillerden alınmış, dilimize henüz yerleşmemiş kelimelerin Türkçelerini kullanır." kazanımının karşılığı yoktur. "Dinlediklerinde/izlediklerinde yabancı dillerden alınmış kelimeleri fark eder." şeklinde bir kazanım ifadesi eklenebilir. Çünkü yabancı dilden alınıp Türkçeye yerleşmeyen bir kelimeyi kullanmamak için onun Türkçe olup olmadığ1nı ayırt etmek/bilmek gerekmektedir.

SİÖA'da not almayla ilgili bir kazanım bulunmamaktadır. Program hazırlayıcıları not almayı bir strateji olarak değerlendirmişler, sïÖA başlığı altındaki açıklamalarda bunu vurgulamışlardır (bk. MEB 2015: 6). Ancak yöntemsel eylemin davranış ifadesine dönüştürülmemesi eksiklik olarak yorumlanabilir. "Dinlediklerindeki/izlediklerindeki önemli bilgileri not alır." şeklinde bir kazanıma ihtiyaç duyulmaktadır. Çünkü "not alma" bütün dil becerilerini bir araya getirebilir. Dinlediğini/izlediğini (dinleme/izleme) ya da okuduğunu (okuma) not almak (yazmak), sonra bir konuşmasında (konuşma) bu notu aktarmak bütün dil becerilerini birleştirmektedir. Bu önemli eksiklik, Program'da belirtilen bütüncül bakış iddiasını desteklememektedir. Dramatize etme de bir yöntemdir. Ancak 1-8. sinıflarda “...metinleri dra- matize eder." şeklinde iki kazanım bulunmaktadir. Bu durum program tasarlamada ve kazanım yazmada tutarsızlıkların sergilendiğini göstermektedir.

Konuşmayı ilgilendiren "Hazırlıklı konuşma/sunu yapar." ifadesinin hazırlıksız yönüyle ilgili bir kazanım yoktur. Özbay (2010), önceki programda da eksiliği tespit etmiş ve "Hazırlıksız konuşma yapar." kazanımına yer verilmesi gerektiğini vurgulamıştır.

Öğrencinin kendi konuşmasını değerlendirmesiyle ilgili bir kazanımın yokluğu dikkat çekicidir. Kendini değerlendirme üstbilişsel bir işlem gerektirir. Kendini eleştirmeye, konuşmasında eksiklikleri, yanlışları belirlemeye dönük bir kazanım ifadesinin olmaması önemli eksikliklerden biri olarak görülebilir.

Önceki programların (MEB, 2005; MEB, 2006) "Konuşmasında ana fikri vurgular.", "Konuşmasinda ana fikri destekleyici ayrintıları vurgular.", "Konuşma öncesinde konuyla ilgili açıklama yapar.", "Konuşmasını bir ana fikir etrafinda planlar.", "Ana fikri yardımcı fikirlerle destekler." kazanımları; dinleme ve konuşma öğrenme alanları ayrı olmasına rağmen birbirine karşılık olabilecek bilişsel işlemleri dikkate alarak hazırlandığını kanıtlamaktadır. Yeni Program sözlü iletişim öğrenme alanında ana fikir, yardımcı fikir üzerine konuşmasını planlama ya da yapılandırmayla ilgili bir kazanım bulunmamaktadır. "Hazırlıkl konuşma/sunu yapar." kazanımına bağlı olarak bu bilişsel işlemin gerçekleşmesi konu, ana fikir, yardımcı fikir bağlamında gerçekleştirilir. Ancak bu kazanımın açıklaması şöyledir: “Topluluk önünde konuşulacak/tartışılacak konu/sunu yapması için hazırlık yapması, gerekli metinleri okuyarak veya çalışarak gelmesi, konuşmasını edindiği bilgiler üzerine kurgulaması, konu ile ilgili kanitlara atıflar yapması, prova yapması ve sunması sağlanır." Yani örtük olarak "Hazırlık evresinde konu, ana fikir, yardımcı fikirlerin düzenlenir.” anlamı çıkarı- 
labilir. Sonuçta dinlemede öğrencinin konu, ana fikir, yardımcı fikirleri belirlemeye yönelik girişimlerde bulunması kazanım olarak yazılırken konuşmada bu zorunlu girişimler kazanımlara yansımamaktadır. Bu tespit, 1981 İlköğretim Okulu Türkçe Programı'ndaki dinleme ve konuşma ilişkisizliğini göstermektedir.

\section{SONUÇ}

Bu çalışmada SİÖA'daki kazanımların ve ifade sorunlarının değerlendirmesiyle şu sonuçlara ulaşılabilir:

Program kitapçığındaki başlıklar altında sunulan bilgiler okunup incelendiğinde programla ilgili bilgi ve açıklamaların yetersizliği dikkat çekmektedir. Kazanımlarla ilgili de yeterli açıklama bulunmamaktadır. Bu durum, birçok probleme yol açmakla birlikte, uygulayıcılara esneklik sağlamaya çalışıldığına işaret edebilir. Program'da öğrenme alanlarının bütün olduğu, kazanımların belirli bir hiyerarşiyle tasarlandığ1 vurgulanmaktadır. Ancak sözlü iletişimde diğer öğrenme alanlarının ilişkisinin açık biçimde kurulamamış olması, bazı kazanımların sınıflara dağılımında kesintilerin olması, bağlantıların kurulamaması bütünlüğü ve hiyerarşik yapıyı tartışmalı hâle getirmiştir. “Eğitim programı içerisinde yer alacak konu başlıklarının tartışmaya yer vermeyecek şekilde açık ve eksiksiz olarak hazırlanması programın başarısını da beraberinde getirecektir" (Temizyürek ve Balc1, 2006: 461).

Kazanım tablosu incelendiğinde, Program'ın giriş kısmında da belirtildiği gibi, ardışıklığa ya da sarmallığa göre hazırlandığı anlaşılmakla birlikte açık bir biçimde, mantığını ve işlevselliğini gösteren bir bilgi ya da yönergeye rastlanmamaktadır. Bilgiyi çıkarımla sağlayabilecek örneklerin, yeterliliği ve tutarlılığı tartışmalıdır. Ön koşul bildiren bazı kazanımlar vardır ancak süreklilik göstermemektedir. Uygula- mada ön koşul bildiren kazanımların dikey ilişkilerinin nasıl kurulacağı belli değildir.

Önceki programlardaki (MEB, 2005; MEB, 2006) dinleme ve konuşma öğrenme alanlarıyla karşılaştırıldığında kazanım sayısının azalması olumlu bir yaklaşım olarak değerlendirilebilir. Sözlü iletişim öğrenme alanında kazanımların sınıflara dağıtılmasında sayısal olarak bir dengenin gözetildiği anlaşılmaktadır. Ancak bazı kazanımların ara sınıf düzeylerinde sonrasız, bazılarının öncesiz olması, bazılarının kesintiye uğraması, bazılarının sürekli olmaması ardışıklık dengesini bozan bir unsur olarak görülebilir. Buna, özetlemeyle ve ön bilgilerle karşılaştırmayla ilgili kazanımların sadece beşinci sınıfta yer alması örnek gösterilebilir.

Sözlü iletişim öğrenme alanında çekirdek kazanım olarak değerlendirebilecek kazanımların niteliği ve niceliği yetersiz görülebilir. Ön koşul ilişkisi ve yapılandırma bağlantılarını kurma açısından başka kazanımların da çekirdekleşmesine ihtiyaç duyulmaktadır.

Kazanım ifadelerinden bazıları anlamada güçlüğe, karışıklığa ve karmaşıklığa sebep olmaktadır. Program'da bazı kazanımların uygulanmasında ipucu olarak parantez içinde belirtilen yönerge sayılabilecek birkaç cümlelik ifadeler karmaşık biçimde açıklanmaya çalışılmıştır. Bu açıklamaların çoğu önceki programlarda birer kazanım olarak yer almaktadır.

Kazanımlar arasında binişiklik göreceli olarak az olmasına rağmen bir kazanımın birden fazla yarg1 bildirmesi ölçme ve değerlendirme açısından önemli bir sorun olarak değerlendirilebilir.

Dil becerilerinin birbirini desteklediği (örn. Sever, 1997; Özbay ve Melanlıoğlu, 2012) bilinen ve Program'da da vurgulanan bir durumdur. Ancak dinleme/izleme ve konuşma ilişkisi çerçevesinde bazı kazanımlar, birbiriyle ilişkisiz ya da karşılıksızdır. Örneğin dinle- 
me/izlemede ana fikir belirleme varken konuşmada ana fikri ifade etme ya da vurgulama gibi bir kazanımın olmaması karşılıksızlı̆̆ı göstermektedir. Dört dil becerisini bir araya getiren not almayla ilgili bir kazanımın eksikliği Program’ın bütünlüğünü bozan bir unsur olarak görülebilir.

Bayburtlu'ya (2016: 157) göre genel itibariyle 2015 programı, 2006 programının karmaşıkl1ğından kurtarılarak daha net ve anlaşılması kolay bir sistemle hazırlanmıştır. Çalışmamızın sonuçlarına göre ise sözlü iletişim öğrenme alanındaki kazanımların 2005 ve 2006 programlarına oranla anlaşılması zor, net olmayan ve karmaşık bir sistemle hazırlandığı anlaşılmaktadir.
Bulgu ve yorumlarda işlenen ve sonuçta ifade edilen sorunların temelinde, Program'da, temel yaklaşımının net ve ayrıntılı biçimde anlatılamaması, örüntü bağlantılarının kurulamaması yatmaktadır. Bunun için Program'da daha fazla açıklama, uygulayıcılar için daha fazla işlevsel bilgilerin bulunması gerekmektedir. Program'da köklü ve önemli bir değişiklik yapılmayacaksa yukarıda belirtilen eksikleri giderici bilgilerin verildiği; bir kazanımda birden çok yargının bulunmadığı, muğlak ifadelerden arındırılmış, dinleme ve konuşma ilişkilerini birlikte gösterebilecek nitelikli kazanım ifadelerinin bulunduğu "zeyl (ek)" niteliğinde bir kılavuz hazırlanmalıdır.

\section{Kaynakça}

Bayburtlu, Y. S. (2016). 2015 Türkçe Dersi Öğretim Programı ve 2006 Türkçe Dersi Öğretim Programının Değerlendirilmesi. Turkish Studies International Periodical for the Languages, Literature and History of Turkish or Turkic, 10 (15), 137-158.

Büyükkaragöz, S. S. (1997). Program Geliştirme Kaynak Metinler. Konya: Öz eğitim, 2. bsk.

Demirel, Ö. (2000). Kuramdan Uygulamaya Eğitimde Program Geliştirme. Ankara: Pegem A, 3. bsk.

Doğanay, A., Sarı, M. (2006). Öğretim Amaçlarının Belirlenmesi, İfade Edilmesi ve Uygun İçeriğin Seçilmesi. Ö̆̆retimde Planlama ve Değerlendirme (Ed. A. Doğanay ve E. Karip). Ankara: Pegem Akademi, 2. bsk.

Güzel, A. ve Karadağ, Ö. (2013). Anlatma Becerileri Açısından Türkçe Dersi Öğretim Programı (6, 7, 8 . Sınıflar)'na Eleştirel Bir Bakış. Ana Dili Eğitimi Dergisi, 1 (1), 45-52.

Karadă̆, Ö. (2012). Anlama Becerileri Açısından Türkçe Dersi Öğretim Programı (6, 7, 8. Sınıflar)'na Eleştirel Bir Bakış. Cumhuriyet Üniversitesi Sosyal Bilimler Dergisi, 36 (1), 97-110.

MEB (2000). Illköğretim Okulu Türkçe-Yazı Programı (6-7-8. Sınıf). İstanbul: Millî Eğitim, 2. bsk.

MEB (2005). İlköğretim Türkçe Dersi (1-5. Sinıflar) Öğretim Programı. Ankara: Millî Eğitim.

MEB (2006). Illköğretim Türkçe Dersi (6, 7, 8. Sinıflar) Öğretim Programı. Ankara: Millî Eğitim.

MEB (2015). Türkçe Dersi (1-8. Sınıflar) Öğretim Programı. Ankara: Millî Ĕ̆itim.

MEB (2015). Türk Dili ve Edebiyatı Dersi (9, 10, 11, 12. Sınıflar) Öğretim Programı. Ankara: Millî Eğitim.

Ornstein, A. C. ve Hunkins, F. P. (2014). Eğitim Programı Temeller, İlkeler, Sorunlar. (çev. ed. A. Arı). Konya: Eğitim (Eserin orijinali 1993'te yayımlandı). 
Özbay, M. (2010). Yeni İlköğretim Türkçe Dersi Öğretim Programı (6, 7, 8. Sınıflar)'nın Kazanımlarına Eleştirel Bir Bakış. Türkçe Öğretimi Yazıları. Ankara: Öncü Kitap.

Özbay, M. ve Melanlığlu, D. (2012). Türkçe Öğretim Programlarının Dinleme Becerisi Bakımından Değerlendirilmesi. Turkish Studies Turkish Studies International Periodical for the Languages, Literature and History of Turkish or Turkic, 7 (1), 87-97.

Temizyürek, F. ve Balcı, A. (2006). Cumhuriyet Dönemi Illköğretim Okulları Türkçe Programları. Ankara: Nobel. 


\section{Extended Summary}

The needs of a society or an individual and the impact of technological development are considered during the preparation of a course curriculum. In addition, educational philosophy, history of education, sociology of education and psychology of educaton are revised for the solution of the problems in existing programs. They can be renewed depending on certain theories, models, connections and research. Turkish Language Teaching Program, has been renewed due to this factors and the changes in the national education system.

The new program has eliminated the distinction of 1-5th and 6-8th grades in the previous program and combined these grades as 1-8th classes. Listening and speaking skills which were distict learning areas in the previous program, are combined as Oral Communication Learning Area. This study is aimed to evaluate the combined learning area according to self-assesment approach. The results of evaluation can be summarized as follows:

It is emphasized in the programme that the learning areas are complete and the acquisitions are designed with a specific hierarchy. However, the fact that relation in other learning areas and learning area of oral communication has not been established clearly and the lack of distribution of achievements to classes, has brought integrity and hierarchical structure to a controversial case.

As it is stated in the introduction of the program, there is no information or instruction indicating the logic and functionality, although it is clearly understood that it is prepared according to sequence or spirality. Adequency and consistency of the samples/examples that can supply information by deduction are controversial. There are some achievements stating prerequisite, but they are not sustainability.

The fact that some acquisitions have no begining, some of them have no ending, some of them are interrupted, some of them are not continious at intermediate grade levels can be seen as a factor that disturbs the balance of sequence. The fact that acquisitions about summering and comparing with prior knowledge take place only in the fifth grade can be shown as an example fort this case.

Some of the acquisition expressions leads to ambiguity in understanding. The expressions that consisted of a few sentences that can be considered as instructions indicated in brackets as a hint are shown in complex ways.

Although comorbidity between acquisitions is relatively less/poor, the fact that an acquisition has more than one judgement can be considered as an important problem in terms of measurement and evaluation.

Within the framework of the relationship between listening / monitoring and speech skills some acquisitions are unrelated to each other or unrequited. The lack/deficiancy of the acquisition related to noting that brings together four language skills can be seen as a factor that disturbs the integrity of the program.

Unless a drastic/radical and significant change would be made in the programme, a guide which has the characteristic of "appendix" containing the relationship between listening and speaking skills together, has qualified and sufficient acquisition expressions, supplies the information containing the foregoing deficiencies, whose acquisition has no more than one judgement, has no ambiguities. 